\title{
A Test on Adverse Selection of Farmers Decision to Purchase Crop Insurance
}

\author{
Rizky Yanuarti ${ }^{1}$, M. Rondhi ${ }^{2}$, Joni Murti Mulyo Aji ${ }^{2}$ \\ \{rizkyyanuarti@gmail.com\} \\ Student of Agribusiness Master Program, University Of Jember ${ }^{1}$, Lecturer of Agribusiness Master \\ Program, University Of Jember ${ }^{2}$
}

\begin{abstract}
Adverse selection is one of an operating risk of crop insurance. This happens because farmers have complete knowledge of their farming condition while the insurer is not. Adverse selection can influence farmer decision to buy crop insurance and make insurer pay more claim than the expected. Based on survey data on AUTP collected by questionnaires in Wuluhan Sub-District, Jember, the paper used logistic regression to estimate the relationship between conditions for crop production and farmers' insurance decision in order to test the existence of farmers' adverse selection. Due to adverse selection, it's expected that farmers with more risk should be more likely to buy crop insurance in pursuit of the benefits from AUTP. However, the result concluded there is no existence of adverse selection. High rate premium subsidy from governments at all levels can possibly defuse farmers' adverse selection under the current system of crop insurance.
\end{abstract}

Keywords: Adverse Selection, Agricultural Insurance, Rice Farming.

\section{Introduction}

Sustainability of agricultural sector, especially the rice crop, which is still the main food for most Indonesians, need attention. There are many things that can interfere with the success of the rice harvest, it can be said that rice farming faces a variety of risks. There are several causes of uncertainty that affect the agricultural sector, which is related to natural factors such as drought, pests and diseases, flood, fire, landslide, and volcanic eruption [1]. Another factors are price fluctuation (input and output), a technology that causes low productivity and production, the action of other parties (sabotage, seizure, and changes in regulations), as well as the condition of farmers or families (dead, seriously ill). The incidence of droughts and floods are the two main causes of crop failure in Indonesia. Global climate change also affects the uncertainty of rice farming [2]. Climate change exacerbates the effects of natural hazards.

The state through government is expected to be present to provide protection and empowerment to farmers who play an important role in the development of the agricultural sector in order to manifest food sovereignty, food independence, and sustainability of food security. One form of protection for farmers' income or welfare is agricultural insurance. Implementation of agricultural insurance become the responsibility of the government in accordance with the mandate of Law 19 of 2013 concerning Farmer Protection and Empowerment, which in the eighth section, Article 37 explained about agricultural insurance. In addition, Article 39 paragraph (1) and (2) of Law 19 of 2013 state that in accordance with 
their authority, central government and regional government facilitate each farmer to become an insurance participant. One form of implementing agricultural insurance is through Rice Farming Business Insurance (AUTP) [3].

Implementation of AUTP will succeed if it is supported by the active role of all stakeholders, both central and regional (provinces, districts, and cities). Before the adoption of AUTP nationally, the government implemented several pilot projects throughout 2012-2014. The pattern of premium payments comes from partnerships. It is cooperating with PT. Pupuk Indonesia Holding Company which is carried out with its subsidiaries, namely PT. Gresik Petrochemical Fertilizer, PT. Pupuk Sriwijaya, Pupuk Kujang, and Japan International Cooperation Agency (JICA) as contributors who pay a premium of 80 percent. Twenty percent of the premium is paid independently by farmers. The insurance company, as the insurer is PT. Jasindo Insurance. AUTP pilot project was carried out in three provinces, namely East Java, West Java Province and South Sumatra [4]. Expansion of AUTP implementation with national scale coverage was held starting in 2015.

Farmers with a relatively high-level perception of risk generally will decide to take part in an insurance program, so there will be an information inequality potential (asymmetric information) between the insurer and the farmer as an insurance participant (insured). This happened because the farmer has complete and perfect knowledge about the condition of the land and his farm while the insurer is not aware of the complete information. This information imbalance can cause deviations, one of which is adverse selection. Insurance participants with greater risk are more likely to participate in the program while those with low risk tend not to participate. This results in the emergence of potential greater losses for the insurer and government [5][6].

The focus of agricultural insurance research in Indonesia mainly about agricultural insurance models that suitable to be applied in Indonesia, for example feasibility and perspective of developing rice and corn insurance [7][8], and specifically climate insurance models, which was still focused on the design of agricultural insurance models in Indonesia [9]. Research that addresses the existence of adverse selection in the implementation of agricultural insurance has been carried out in China[10][11]. Adverse selection affects the farmer's decision to take insurance. However, the condition of agricultural insurance in Indonesia, which had just entered its fifth year, will certainly be different from other countries such as China which have already applied agricultural insurance for a longer period.

In fact, not all farmers follow agricultural insurance. This can be caused by various factors. One of them was the attitudes and perceptions of farmers about the risks faced. Provision of premium subsidy was expected to spur farmers both high and low risk to participate in AUTP. Besides giving a good impact, there were potential impacts of deviation from farmers. Provision of premium subsidy, same premium value according to the law, and equal requirements for prospective insurance participants made the potential for information asymmetry in the form of Adverse Selection possible. The purpose of this study is to examine the existence of adverse selection in AUTP implementation in Indonesia. Logistic regression method was used in this study. The results of the study were expected to be used as an improvement of AUTP research in Indonesia. 


\section{Research Method}

This research was conducted in Wuluhan District, Jember Regency because AUTP procedure was identical in all region in Indonesia (refer to UU No. 19 of 2013 article 37). The insurance company that handles AUTP in Jember was Jasindo so the implementation guidelines would be the same. The number of samples used was 130 farmers from a total population of 361 farmers (determining the amount of sample by using Slovin formula). The sample was divided into two groups, namely the treatment group (following AUTP) and the control group (who did not participate in AUTP), each consisting of 65 farmers.

The variable used to determine the existence of adverse selection was the existence of irrigation on farmers' land. The use of irrigation and drainage as an indicator of farmer land quality [11]. In line with this, the other researchers state that land with irrigation tends to be at lower risk[12][13]. Another variable used was farmers' experience of crop failure due to pests. The used of these variables were intended to determine farmers understanding of the risks and would directly affect farmers' decision to protect their farming by participating in AUTP. The variables mentioned were then analyzed using logistic regression. Other factors used in the regression model were described in the following table.

Table 1. Logistic Regression Variable Description

\begin{tabular}{|c|c|c|c|}
\hline & Factors & Units & Description \\
\hline $\bar{Y}$ & Insurance Choice & & $\begin{array}{l}\text { Whether or not farmers were involved in } \\
\text { AUTP in 2018; } 1 \text { represents being } \\
\text { involved0 represents not being involved }\end{array}$ \\
\hline $\mathrm{X} 1$ & Risk Aversion Level (RAL) & MSI & $\begin{array}{l}\text { RAL was obtained by using perception } \\
\text { method. There were six choices that farmer } \\
\text { can choose from risk-averse to risk lover. } \\
\text { The ordinal data were transformed into } \\
\text { interval using successive interval method } \\
\text { (MSI) }\end{array}$ \\
\hline $\mathrm{X} 2$ & Age & Year & Farmer age \\
\hline $\mathrm{X} 3$ & Farming Experience & Year & Farmer experience in farming \\
\hline $\mathrm{X} 4$ & Land Area & Hectare & The rice area in each household \\
\hline X5 & Existence of Irrigation & $\begin{array}{l}1=\text { exist; } 0= \\
\text { not exist }\end{array}$ & $\begin{array}{l}\text { Existence of irrigation in each farmer land. } \\
\text { Also represent land quality [11] }\end{array}$ \\
\hline $\mathrm{X} 6$ & $\begin{array}{l}\text { Experience of crop failure due } \\
\text { to pests }\end{array}$ & $\begin{array}{l}1=\text { ever; } \\
0=\text { never }\end{array}$ & $\begin{array}{l}\text { Farmer experience in harvest failure can be } \\
\text { used to represent farmer awareness of } \\
\text { farming lost }\end{array}$ \\
\hline
\end{tabular}

Based on Table 1, the used logistic regression model are as follow :

$$
Y_{i}=\ln \left(\frac{p_{i}}{1-p_{i}}\right)=\frac{\mathrm{e}^{b 0+b_{1} X_{1}+b_{2} X_{2}+b_{3} X_{3}+b_{4} X_{4}+b_{5} X_{5}+b_{6} X_{6}}}{1+\mathrm{e}^{b 0+b_{1} X_{1}+b_{2} X_{2}+b_{3} X_{3}+b_{4} X_{4}+b_{5} X_{5}+b_{6} X_{6}}}
$$

The main focus of this paper was to detect the possibility of adverse selection in farmers' decision to buy crop insurance. It was already mentioned before that irrigation, and farmers' harvest failure experience were used to detect adverse selection. Meanwhile, to do logistic regression, it needed to use another variable for a complement. The complement variables 
were mention in Table 1, namely Risk Aversion Level (RAL), farmer age, farming experience, and rice acreage. If the significance value of the land irrigation system and harvest failure experience $\leq 0.05$, it can be said that there was an adverse selection in the farmers' decision to participate in AUTP. But if the significance value of the land irrigation system and harvest failure experience $>0.05$, there was no adverse selection in the farmers' decision to participate in AUTP.

\section{Result and Discussion}

Rice Farm Insurance (AUTP) was a program created by the government to protect farmers from the risk of crop failure due to floods, droughts, and pest attacks. All farmers can participate in AUTP by fulfilling the requirements. AUTP was considered to be very useful for farmers because if farmers experience crop failure, they can submit claims and receive compensation of $\operatorname{Rp~} 6,000,000$ per hectare. The premium that must be paid by farmers gets a subsidy of $80 \%$, leaving a premium fee of Rp. 36,000 / hectare / planting season. Regarding the farmers' decision to participate in AUTP and factors that influenced the decision, logistic regression analysis was used. The results of this analysis can be used to detect the presence of adverse selection through the two variables that were the existence of irrigation and experience of crop failure due to pests.

Table 2. Result of Logistic Regression Analysis

\begin{tabular}{lrrrrrr}
\hline & $\begin{array}{c}\text { B } \\
\text { (Variable } \\
\text { Coef.) }\end{array}$ & $\begin{array}{c}\text { S.E. } \\
\text { (Standard } \\
\text { Error) }\end{array}$ & Wald & Df & Sig. & $\begin{array}{c}\text { Exp(B) } \\
\text { (Odds } \\
\text { Ratio) }\end{array}$ \\
\hline Risk Aversion Level & $-1,531$ & 0,308 & 24,777 & 1 & 0,000 & 0,216 \\
Age & $-0,048$ & 0,029 & 2,739 & 1 & 0,098 & 0,954 \\
Farming Experience & 0,096 & 0,042 & 5,271 & 1 & 0,022 & 1,101 \\
Land Area & 1,738 & 0,566 & 9,419 & 1 & 0,002 & 5,687 \\
Harvest Failure due to pest & 1,270 & 0,562 & 5,109 & 1 & 0,024 & 3,562 \\
Constant & 2,045 & 1,305 & 2,455 & 1 & 0,117 & 7,729 \\
\hline
\end{tabular}

In Table 2, it can be seen that risk aversion level, farming experience, land area and experience of harvest failure due to pests have a wald test significance value of $<0.05$ which were respectively the following 0,$000 ; 0.022 ; 0,002$; and 0.024 . Age variable has a significance value of $0.098(<0.1)$. So that it can be said that five variables were significant at the level of $95 \%$ and $90 \%$. Meanwhile, the existence of irrigation systems variable cannot be included in the analysis process. This was because in the research area, it was found that members of farmer group who were used as samples all had technical irrigation systems. The same value in all research samples caused an analysis of that variables cannot be done.

The logistic regression equation model obtained based on Table 2 was as follow:

$$
Y_{i}=\frac{\mathrm{e}^{2,045-1.531 X_{1}-0,048 X_{2}+0,096 X_{3}+1,738 X_{4}+1,270 X_{6}}}{1+\mathrm{e}^{2,045-1.531 X_{1}-0,048 X_{2}+0,096 X_{3}+1,738 X_{4}+1,270 X_{6}}}
$$

Based on logistic regression result of RAL variable, we can conclude that the result was consistent with a previous study [10] which stated that farmers with high risk aversion and 
large planting areas would be willing to participate in agricultural insurance. Conversely farmers with low risk aversion and small land areas will refuse to participate, or in other words, Farmers who do not like risk will tend to participate in insurance. Younger farmers had a higher potential to participate in AUTP. Older farmers may found it difficult to receive and learn new products because they feel that they had enough experience to overcome the risks of rice farming. This result was consistent with the other study, which stated that young farmers were more likely to adopt and follow agricultural insurance [14][15].

Farmers' experiences made farmers have a better knowledge of seeing, assessing, and understanding risks. This made farmers able to assess that AUTP was alternative risk management in dealing with conditions of agricultural uncertainty and global climate change or extreme weather. This result was consistent with the other study, which stated that farmer experience had a positive impact on corp insurance participation [16]. Farmers with a larger land area had higher risk exposure and tend to use agricultural insurance more often. This result was consistent with the previous study which stated that the planting area was estimated to have a positive sign with the farmer's decision to buy crop insurance[11].

Adverse selection occurs because of the imperfection of information provided by AUTP participants to the insurer. Farmers had complete and perfect knowledge of the conditions of their farming, but the insurer was not. The existence of irrigation systems was expected to be a comparative indicator of land quality. Farmers who have an irrigation system will tend not to buy insurance [17]. Another research found different things that didn't find pattern showed that high-risk groups (without irrigation) tended to buy insurance compared to low-risk groups (having irrigation) [11]. So it was concluded that there was no adverse selection behavior in the farmers' decision.

Next, because the research area was found that farmers as a whole already had an irrigation system, it was important to look at research with similar conditions. The condition of irrigated farmer land, adverse selection can be tested by looking at the type of insurance purchased [18]. This can be done because there were several types of insurance that can be chosen by farmers. So that the pattern of purchasing insurance can be used as an indicator of the existence of adverse selection, for example during the dry season farmers will tend to buy land insurance and income, but in good weather conditions, farmers will tend to reduce insurance purchases.

Another adverse selection indicator was the experience of crop failure due to pests. The logistic regression analysis result showed that the regression coefficient obtained was 1.27 , it can be interpreted that if the farmer has experienced crop failure due to pests, it will increase the chances of farmers to follow AUTP by 1.27. The oods ratio which was an Exp (B) value of 3.562 , indicated that farmers with experience of crop failure due to pests have a tendency to follow AUTP by 3.562 times smaller than farmers who have not experienced crop failure due to pests. This variable had a significant influence on farmers' decisions to follow AUTP (see table 2).

This result is consistent with another researcher, which stated that farmers tend to depend on experience when making decisions to buy insurance [17]. So that it can be interpreted that farmers who have experienced crop failure due to pests already know and feel the losses caused, and assess that AUTP was an appropriate alternative risk solution. This was reinforced by the fact that in the research area, the insurance claim process runs smoothly and according to the procedures that have been carried out. The progress of the insurance claim process had encouraged farmers to continue to become a participant of AUTP and those who have not participated to be interested in trying. 


\section{Conclusion}

Based on the analysis, it can be concluded that there was no adverse selection in a farmer's decision to follow AUTP in Jember. These results indicate that the hypothesis was rejected. This was because in the research area, the farmer as a whole already had a technical irrigation system, so it can be said that there was nothing to hide about the condition of farmer's land. In addition, although the variable crop failure due to pests has a significant influence on farmers' decisions, this information was not something farmers will hide. Another reason was the high subsidies provided by the government reach $80 \%$ of the total premiums to be paid, so AUTP was attractive to low-risk and high-risk farmers, as stated in another study [13]. Future research is expected to be carried out with a wider research area. So that the application of AUTP to land with diverse conditions can be analyzed properly.

\section{References}

[1] R. Ullah, G. P. Shivakoti, and F. Zulfiqar, "Farm risks and uncertainties : Sources , impacts and management," Outlook Agric., vol. 45, no. 3, pp. 199-205, 2016.

[2] R. Boer, "Asuransi Iklim Sebagai Jaminan Perlindungan Ketahanan Petani Terhadap Perubahan Iklim," in Prosiding Widyakarya Nasional Pangan dan Gizi 10: Pemantapan Ketahanan Pangan dan Perbaikan Gizi Berbasis Kemandirian dan Kearifan Lokal, 2012, p. 2012.

[3] A. Fariyanti, T. Sarianti, and Y. N. Mufflikh, "Willingness To Pay dan Ability To Pay Petani dalam Asuransi Pertanian," in Menuju Agribisnis Indonesia yang Berdaya Saing, B. Krisnamurthi and Harianto, Eds. Bogor: Departemen Agribisnis Fakultas Ekonomi dan Manajemen IPB, 2017, pp. $153-162$.

[4] A. A. et al Sulaiman, Asuransi Pengayom Petani. Jakarta: Sekertaris Jenderal Kementrian Pertanian RI, 2017.

[5] R. G. Chambers, "Insurability and Moral Hazard in Agricultural Insurance Markets," Am. J. Agric. Econ., vol. 71, pp. 604-616, 1989.

[6] M. J. Miranda, "Area-Yield Crop Insurance Reconsidered," Am. J. Agric. Econ., vol. 73, pp. $233-242 ., 1991$

[7] A. R. Nurmanaf, Sumaryanto, S. W. E. Ariningsih, and Y. Supriyatna, "Analisis Kelayakan dan Perspektif Pengembangan Asuransi Pertanian untuk Usahatani Padi dan Sapi Potong. Bogor," 2007.

[8] Sumaryanto and A. R. Nurmanaf, "Simpul-Simpul Strategis Pengembangan Asuransi Pertanian untuk Usahatani Padi di Indonesia," Forum Penelit. Agro Ekon., vol. 25, no. 2, pp. 89-104, 2006.

[9] B. Aryanti, "Designing Crop Insurance to Help Farmers Transfer Risk of Crops Loss in Rural Indonesia.," in Electronic Seminar Paper, 2014, p. 2014.

[10] K. Lyu and T. J. Barre, "Risk aversion in Crop Insurance Program Purchase Decisions," China Agric. Econ. Rev., vol. 9, no. 1, pp. 68-80, 2016.

[11] L. Hou, D. L. K. Hoag, and Y. Mu, "Testing for adverse selection of crop insurance in northern China," China Agric. Econ. Rev., vol. 3, no. 4, pp. 462-475, 2011.

[12] E. Sihem, "Economic and Socio-Cultural Determinants of Agricultural Insurance Demand Across Countries," J. Saudi Soc. Agric. Sci. . xxx, pp. 1-11, 2017.

[13] Z. et al Yuanfeng, "A Test on Adverse Selection of Farmers In Crop Insurance: Results from Inner Mongolia, China," J. Integr. Agric., vol. 16, no. 2, pp. 478-485, 2017.

[14] M. A. Mohammed and G. F. Ortmann, "Factors Influencing Adoption of Livestock Insurance by Commercial Dairy Farmers in Three Zobatat of Eritrea," Agrekon, vol. 44, no. 2, pp. 172-186, 2005.

[15] E. et al Waimuru, "Factors Affecting Weather Index-Based Crop Insurance in Laikipia County, Kenya," J. Agric. Ext. Rural Dev., vol. 8, no. 7, pp. 111-121, 2016.

[16] B. J. et al Sherrick, "Factors Influencing Farmers' Crop Insurance Decisions," Am. J. Agric. 
Econ., vol. 86, no. 1, p. 2004, 2004.

[17] O. A. Mwe, "An Economic Analysis of Impact of Weather Index-based Crop Insurance on Household Income in Huye District of Rwanda," 2016.

[18] C. G. Walters, C. R. Shumway, H. H. Chouinard, and P. R. Wandschneider, "Asymmetric Information and Profit Taking in Crop Insurance," Appl. Econ. Perspect. Policy, vol. 37, no. 1, pp. 107-129, 2014. 